\title{
Sensory Qualities of Pork from Large White and Windsnyer Gilts Prepared By Different Cooking Methods
}

\author{
James Madzimure ${ }^{1 *}$, Archibald G. Bakare ${ }^{2}$, Voster Muchenje ${ }^{3}$, Michael Chimonyo ${ }^{4}$
}

\begin{abstract}
${ }^{1}$ Department of Animal Production and Technology, Chinhoyi University of Technology, Chinhoyi, Zimbabwe ${ }^{2}$ Department of Agriculture and Animal Health, University of South Africa, Florida, South Africa ${ }^{3}$ Department of Livestock and Pasture Science, University of Fort Hare, Alice, South Africa ${ }^{4}$ Discipline of Animal and Poultry Science, University of KwaZulu-Natal, Scottsville, Pietermaritzburg, South Africa
\end{abstract}

*Corresponding Author: James Madzimure, Department of Animal Production and Technology, Chinhoyi University of Technology, Chinhoyi, Zimbabwe. Tel: +26367 22203-5; E-mail: madzimurej@gmail.com; jmadzimure@cut.ac.zw

\begin{abstract}
The objectives of the current study were to determine sensory characteristics of Large White and Windsnyer gilts' pork cooked by either microwaving or boiling. Pork from 12 pigs of each breed (aged 21 weeks) was served to a semi-trained panel of 66 participants. Windsnyer pork had higher $(\mathrm{P}<0.05)$ scores on initial and sustained impression of juiciness than Large White pork. Microwaved pork had higher $(\mathrm{P}<0.05)$ scores for aroma, first bite impression, sustained juiciness, and the amount of connective tissue, fibre and overall flavour intensity when compared to boiled pork. Most sensory attributes were positively correlated $(\mathrm{P}<0.05)$ to each other with higher coefficients being found in microwaved Windsnyer pork than in microwaved Large White pork. Gender affected sensory attributes with female consumers giving higher scores than male consumers for aroma intensity, initial impression of juiciness and a-typical flavour. The results may suggest that Windsnyer pork cooked by microwave method could be more acceptable to consumers than Large White pork.
\end{abstract}

Keywords: Aroma; Flavour; Pork quality; Juiciness; Tenderness

\section{Introduction}

The pork industry in South Africa is growing with most commercial farmers keeping breeds such as Landrace, Large White, Duroc and Pietrien ${ }^{[1,2]}$. About 1.8 million commercial pigs are slaughtered annually ${ }^{[1]}$ as healthy conscious people prefer pork due to less risk of causing heart diseases. Indigenous South African Windsnyer pigs contribute lowly to commercial pork production because they have slow growth rates, smaller carcasses and tend to deposit fat early when fed on commercial feeds ${ }^{[3-5]}$. Windsnyer pigs are also limited to free-ranging production system ${ }^{[6]}$. Indigenous pigs are kept in small numbers at the household level where they are a source of protein and capital accumulation ${ }^{[7,8]}$. Molecular characterisation provided evidence that indigenous pigs of southern Africa are essentially one genotype ${ }^{[9]}$. It is likely that these pigs produce similar acceptable pork ${ }^{[10]}$. No attempts have been made to objectively assess the pork quality of Windsnyer pigs and its acceptability by consumers. The promotion of organically produced indigenous pork on the market might increase the choices available for the increasing healthy conscious population.
Received Date: June 05, 2015

Accepted Date: September 07, 2015

Published Date: September 10, 2015

Citation: Madzimure, J., et al. Sensory Qualities of Pork from Large White and Windsnyer Gilts Prepared By Different Cooking Methods. (2015) Int J Food Nutr Sci 2(2):106-111.

DOI: $10.15436 / 2377-0619.15 .026$

Consumers prefer pork which is tender, juicy and have no off-flavours ${ }^{[11,12]}$. Boars end to produce pork with such off-flavours. Flavour is a complex parameter of meat palatability that is determined by senses of smell and taste. Flavour is also affected by the quantity and composition of $\mathrm{fat}^{[13-15]}$. Aroma, the impression that forms on the first bite of the meat and the amount of the connective tissue in meat is also an important sensory characteristic ${ }^{[16,17]}$; and are affected by various factors such as genotype, sex, slaughter conditions, post-mortem aging, $\mathrm{pH}$, additives, cooking method and consumer background ${ }^{[18]}$.

Aaslyng, et al. ${ }^{[11]}$ reported that cooking procedure (heating time or heating temperature) and heating method affects sensory characteristics of pork. High cooking temperatures and high cooking loss- 
es reduce juiciness of beef ${ }^{[19]}$. Cooking by the boiling method (stewing) is the most common cooking method in developing countries. Ngapo, et al. ${ }^{[20]}$ also reported that pork can either be roasted or grilled. The advances in technology have, however, seen the widespread use of advanced heating and cooking appliances such as microwaves. Microwaves are energy-saving, easy and quick to prepare foods ${ }^{[21,22]}$ such as pork. Microwaves above 450 watts can allow adequate cooking of pork to a temperature that allows reduction of pathogenic bacteria to acceptable lev$\mathrm{e}^{[21,23]}$. Microwaved meat products have lower moisture content, aroma score, flavour score and palatability than conventional hot air oven ${ }^{[24-26]}$. It is, however, not known how different cooking methods affect the eating quality and general acceptability of pork from indigenous Windsnyer pigs. Large White gilts were used as bench-mark since it is the breed commonly used for pork production in South Africa. Gilts do not produce pork taints and their pork quality is expected to be best because of their young age.

There is need to establish how the sensory characteristics of meat prepared by different cooking methods relate to each other and consumers' backgrounds. The objectives of the current study were: 1) to determine sensory characteristics of pork from Large White and indigenous Windsnyer gilts prepared by different cooking methods; and 2) determine effect of consumer background on pork sensory characteristics.

\section{Materials and Methods}

\section{Site and Management of Pigs}

The pigs were kept at the Fort Cox College of Forestry and Agriculture in the Eastern Cape Province of South Africa. The college is situated at $32^{\circ} 45^{\prime} \mathrm{E}$ and $27^{\circ} 03^{\prime} \mathrm{N}$ at about $580 \mathrm{~m}$ above sea level. The experiment was managed following procedures approved by the University of Fort Hare Ethics Committee. Twelve 6-week-old gilts from each of the Windsnyer and Large White breeds were used in the trial. The gilts were obtained from Fort Cox College of Agriculture and Forestry. The management of pigs was similar to the description of Madzimure, et al. ${ }^{[27]}$.

\section{Slaughter Procedure and Sample Storage}

Slaughter of pigs was done at Adelaide abattoir, about $80 \mathrm{~km}$ away from the study site. Pigs were transported during a cool morning, allowed to rest for an hour upon arrival and they were given water ad libitum. They were stunned using the electric stunning method, their jugular veins severed, fully bled and scalded in hot water thereafter. The heads were removed at the atlanto-occipital joint and the hooves were cut off at the proximal end of the cannon bones, leaving the carpal and tarsal bones on the carcass. The $m$. longissimus thoracis (LT) muscle was cut to enable $\mathrm{pH}$, colour measurements at $1 \mathrm{hr}$ post mortem and sensory evaluations. The carcasses were chilled at $0^{\circ} \mathrm{C}$ for 24 hrs. Thereafter, the whole LT for each pig was cut and vacuum packed. The LT samples were kept in the refrigerator at $-4^{\circ} \mathrm{C}$ for two weeks before laboratory analyses.

\section{Cooking Method}

Pork from each of WS and LW pigs were sampled and cut into approximately $3 \mathrm{~cm}$ by $10 \mathrm{~cm}$ strips. These pork strips were divided into two portions for each breed and were cooked by boiling (stewing) or microwaving. Pork samples of each breed were boiled at a temperature of $80^{\circ} \mathrm{C}$ until it attained a core temperature of $70^{\circ} \mathrm{C}$ after about 20 minutes. The remaining pork portion of each breed was microwaved at $65^{\circ} \mathrm{C}$ for 10 minutes ${ }^{[23]}$. One side of the pork strip was heated by microwave for five minutes then turned to the other side for another five minutes. Salt was added on both boiled and microwaved pork to taste. The pork samples were allowed to cool down after preparation. Thereafter, the pork strips were cut into smaller pieces for tasting.

\section{Sensory Analysis}

The meat sensory evaluation was carried out by sixty-six semi-trained panellists. The panellist consisted of Animal Science students from the University of Fort Hare. These students came from different consumer backgrounds namely Shona, Xhosa and Zulu, different age groups $(\leq 20,21$ to 25,26 to $30, \geq 30$ ) and gender (female, male). The sensory panellists were first trained on how to evaluate the pork samples and complete the available forms. The samples were coded with three digit numbers and offered randomly to panellists. An evaluation form containing an eight-point rating scale of pork characteristics was used to give scores to different pork sensory characteristics. The characteristics to test were the initial impression of juiciness (IJ), sustained impression of juiciness (SJ), first bite impression (FB), muscle fibre and overall tenderness (MFT), aroma intensity (AI), overall flavour intensity (OFI), amount of connective tissue (ACT), off-flavour indicators (ATI) and a-typical flavour (ATF). The scores ranged from 1 to 8 , with the higher the scores the acceptable it is, except for off-flavour where lower scores indicate better characteristics. The sensory characteristics ratings were AI $(1=$ extremely bland to $8=$ extremely intense), IJ ( 1 = extremely dry to $8=$ extremely juicy), FB ( $1=$ extremely tough to $8=$ extremely tender $)$, SJ $(1=$ extremely dry to $8=$ extremely juicy), MFT ( 1 = extremely tough, to $8=$ extremely tender $)$, ACT $(1=$ extremely abundant to $8=$ none $)$, OFI $(1=$ extremely bland to $8=$ extremely intense), ATF $(1=$ none to $8=$ extremely intense). The off-flavour indicators were livery/bloody, cooked vegetable, pasture/grassy, animal like/kraal (manure), metallic, sour, unpleasant and others. Waiting period between samples was ten minutes and panellists were also requested to rinse their mouth with tap water after each taste so as to limit crossover or residual effect of the treatments ${ }^{[1]}$.

\section{Statistical Analysis}

General Linear Model (GLM) procedure of SAS (2006) ${ }^{[28]}$ was used to analyse the effect of breed, the cooking method and their interaction on the sensory characteristics of pork. The same procedure was used to analyse the effects of gender, age and consumer background of the participants on sensory characteristics of the pork. Sensory scores were first transformed using $\log 10$ to normalise them. The PDIFF procedure of SAS (2006) was used to compare the least square means. The model used was:

$\mathrm{Y}_{\mathrm{ijk}}=\mu+\mathrm{C}_{\mathrm{i}}+\mathrm{D}_{\mathrm{j}}+\left(\mathrm{C}_{\mathrm{i}} \times \mathrm{D}_{\mathrm{j}}\right)+\mathrm{E}_{\mathrm{ijk}}$

Where:

$\mathrm{Y}_{\mathrm{ijk}}=$ the response variable (aroma intensity, initial impression of juiciness, first bite, sustained impression of juiciness, muscle fibre and overall tenderness, amount of connective tissue, overall flavour intensity, off-flavour indicators and a-typical flavour). 
$\mu=$ overall mean common to all observation;

$\mathrm{C}_{\mathrm{i}}=$ the effect of $\mathrm{i}^{\text {th }}$ breed (Windsnyer and Large White);

$\mathrm{D}_{\mathrm{j}}=$ the effect of $\mathrm{j}^{\text {th }}$ cooking method (microwaving and cooking);

$\mathrm{C}_{\mathrm{i}} \times \mathrm{D}_{\mathrm{j}}=$ interaction between breed and cooking method; and

$\mathrm{E}_{\mathrm{ijk}}=$ random error.

A separate model was used to test for the effects of gender (male, female), age $((\leq 20,21$ to 25,26 to $30, \geq 30)$ and consumer background of the panellists and their interactions on the sensory scores. Correlations of breed and cooking methods versus sensory attributes were computed using PROC CORR of SAS (2006).

\section{Results}

\section{Effect of Breed, Pork Cooking Method and Consumer Back- ground on Sensory Scores}

The effects of breed and cooking method on pork sensory characteristics are shown in Table 1. Overall, breed had no significant effects on most sensory characteristics except on initial and sustained impression of juiciness scores. Boiled pork from Large White pigs had higher $(\mathrm{P}<0.05)$ initial and sustained impression of juiciness scores than boiled Windsnyer pork. Windsnyer pork, however, had higher $(\mathrm{P}<0.05)$ initial and sustained impression of juiciness scores than Large White pork when microwaved. Method of cooking had significant effects on scores for aroma, first bite impression, sustained juiciness, and amount of connective tissue, fibre and overall flavour intensity with microwaved steaks having higher $(\mathrm{P}<0.05)$ scores than boiled ones. Breed and pork cooking method interacted to affect initial juiciness, first bite, sustained impression of juiciness and muscle fibre and overall tenderness.

Table 1: Least square means ( \pm standard error of mean) of sensory scores for Large White and Windsnyer pork prepared by boiling and microwave methods

\begin{tabular}{|c|c|c|c|c|}
\hline \multirow[t]{2}{*}{ Sensory attribute } & \multicolumn{2}{|c|}{ Large White $(\mathrm{n}=12)$} & \multicolumn{2}{|c|}{ Windsnyer $(\mathrm{n}=12)$} \\
\hline & Boiling & Microwave & Boiling & Microwave \\
\hline Aroma intensity & $4.8 \pm 0.22^{\mathrm{ab}}$ & $5.4 \pm 0.22^{\mathrm{bc}}$ & $4.7 \pm 0.22^{\mathrm{a}}$ & $5.5 \pm 0.22^{\mathrm{c}}$ \\
\hline $\begin{array}{l}\text { Initial impression } \\
\text { of juiciness }\end{array}$ & $3.9 \pm 0.21^{\mathrm{b}}$ & $4.7 \pm 0.21^{\mathrm{c}}$ & $3.2 \pm 0.21^{\mathrm{a}}$ & $5.4 \pm 0.22^{\mathrm{d}}$ \\
\hline First bite & $4.2 \pm 0.22^{\mathrm{ab}}$ & $4.6 \pm 0.22^{\mathrm{bc}}$ & $3.9 \pm 0.22^{\mathrm{a}}$ & $5.1 \pm 0.22^{\mathrm{c}}$ \\
\hline $\begin{array}{l}\text { Sustained impres- } \\
\text { sion of juiciness }\end{array}$ & $3.9 \pm 0.20^{\mathrm{a}}$ & $4.7 \pm 0.20^{\mathrm{b}}$ & $3.7 \pm 0.20^{\mathrm{a}}$ & $5.7 \pm 0.20^{c}$ \\
\hline $\begin{array}{l}\text { Muscle fibre and } \\
\text { overall tenderness }\end{array}$ & $4.6 \pm 0.21^{\mathrm{ab}}$ & $4.5 \pm 0.21^{\mathrm{ab}}$ & $4.1 \pm 0.21^{\mathrm{a}}$ & $5.0 \pm 0.21^{\mathrm{b}}$ \\
\hline $\begin{array}{l}\text { Amount of con- } \\
\text { nective tissue }\end{array}$ & $4.2 \pm 0.17^{\mathrm{ab}}$ & $4.4 \pm 0.17^{\mathrm{ab}}$ & $4.1 \pm 0.17^{\mathrm{a}}$ & $4.6 \pm 0.17^{\mathrm{b}}$ \\
\hline $\begin{array}{c}\text { Overall flavour } \\
\text { intensity }\end{array}$ & $4.5 \pm 0.20^{\mathrm{a}}$ & $5.4 \pm 0.20^{\mathrm{b}}$ & $4.4 \pm 0.20^{\mathrm{a}}$ & $5.3 \pm 0.20^{\mathrm{b}}$ \\
\hline $\begin{array}{l}\text { Off-flavour indi- } \\
\text { cators }\end{array}$ & $3.3 \pm 0.25^{\mathrm{ab}}$ & $3.5 \pm 0.25^{\mathrm{b}}$ & $2.7 \pm 0.26^{\mathrm{a}}$ & $3.3 \pm 0.26^{\mathrm{ab}}$ \\
\hline A-typical flavour & $3.3 \pm 0.41^{\mathrm{a}}$ & $3.6 \pm 0.42^{\mathrm{a}}$ & $3.8 \pm 0.44^{\mathrm{a}}$ & $3.5 \pm 0.46^{\mathrm{a}}$ \\
\hline
\end{tabular}

There was no effect of consumer age on scoring of most of the sensory characteristics. The Shona tribe differed from the rest on off-flavour indicators where they reported that the pork had chicken flavour. The results also showed gender differences in sensory scores with female consumers giving higher $(\mathrm{P}<$
$0.05)$ scores than male consumers for aroma intensity, initial impression of juiciness and a-typical flavour (Table 2). On the contrary, male consumers gave higher $(\mathrm{P}<0.05)$ scores than female consumers for off-flavour indicators and amount of connective tissue.

Table 2: Least square means ( \pm standard errors) of gender of consumers' $(n=66)$ effects on sensory characteristics of pork

\begin{tabular}{|c|c|c|}
\hline Sensory characteristics & Male & Female \\
\hline Aroma intensity & $4.6 \pm 0.38^{\mathrm{a}}$ & $5.4 \pm 0.42^{\mathrm{b}}$ \\
\hline Initial impression of juiciness & $4.2 \pm 0.40^{\mathrm{a}}$ & $4.9 \pm 0.44^{\mathrm{b}}$ \\
\hline First bite & $3.9 \pm 0.38^{\mathrm{a}}$ & $4.1 \pm 0.42^{\mathrm{a}}$ \\
\hline Sustained impression of juiciness & $4.1 \pm 0.38^{\mathrm{a}}$ & $4.3 \pm 0.42^{\mathrm{a}}$ \\
\hline Amount of connective tissue & $4.3 \pm 0.28^{\mathrm{b}}$ & $3.9 \pm 0.31^{\mathrm{a}}$ \\
\hline Muscle fibre and overall tenderness & $4.0 \pm 0.35^{\mathrm{a}}$ & $4.4 \pm 0.39^{\mathrm{a}}$ \\
\hline Overall flavour intensity & $4.9 \pm 0.36^{\mathrm{a}}$ & $5.3 \pm 0.39^{\mathrm{a}}$ \\
\hline A-typical flavour & $2.9 \pm 0.85^{\mathrm{a}}$ & $4.2 \pm 0.1^{\mathrm{b}}$ \\
\hline Off- flavour indicators & $3.3 \pm 0.42^{\mathrm{b}}$ & $2.4 \pm 0.46^{\mathrm{a}}$ \\
\hline
\end{tabular}

a,b Means with different superscripts within the same row differ $(\mathrm{P}<$ $0.05)$.

\section{Relationships among Sensory Attributes and Breed and, Cooking Method}

Pearson's correlations among sensory attributes for Large White pork are shown in Table 3. Large White pork had the strongest positive correlation $(\mathrm{P}<0.001)$ between first bite impression, and muscle fibre and overall tenderness. There was also a significantly positive correlation between muscle fibre and overall tenderness and sustained impression of juiciness and, between sustained impression of juiciness and first bite impression for both breeds (Tables 3 and 4). For Windsnyer pork, the strongest positive correlation was between sustained impression of juiciness and initial impression of juiciness, followed by between first bite impression, and muscle fibre and overall tenderness (Table 4). In Windsnyer pork, there was a significant positive correlation between off-flavour indicators, and muscle fibre and overall tenderness. There was a strong positive correlation $(\mathrm{P}<0.001)$ between first bite impression, and muscle fibre and overall tenderness for both boiled and microwaved pork (Tables 5 and 6). Boiled pork also had strong positive correlations between sustained impression of juiciness and first bite impression, followed by correlation between muscle fibre and overall tenderness, and sustained impression of juiciness (Table 5). Microwaved pork had strong positive correlations $(\mathrm{P}<0.001)$ between initial impression of juiciness and sustained impression of juiciness, followed by first bite impression and sustained impression of juiciness and, lastly between muscle fibre and overall tenderness, and sustained impression of juiciness (Table 6).

Table 3: Pearson's correlations of sensory attributes for Large White pork

\begin{tabular}{|l|l|l|l|l|l|l|l|l|l|}
\hline & AI & IJ & FB & SJ & MFT & ACT & OFI & ATI & ATF \\
\hline AI & - & & & & & & & & \\
\hline IJ & $0.19^{*}$ & - & & & & & & & \\
\hline FB & 0.15 & $0.20^{*}$ & - & & & & & & \\
\hline SJ & $\begin{array}{l}0.3 \\
4^{* * *}\end{array}$ & $\begin{array}{l}0.4 \\
8^{* *}\end{array}$ & $\begin{array}{l}0.6 \\
2^{* * *}\end{array}$ & - & & & & & \\
\hline MFT & 0.09 & $\begin{array}{l}0.3 \\
0^{* * *}\end{array}$ & $\begin{array}{l}0.6 \\
7^{* * *}\end{array}$ & $\begin{array}{l}0.5 \\
6^{* * *}\end{array}$ & - & & & & \\
\hline
\end{tabular}




\begin{tabular}{|l|l|l|l|l|l|l|l|l|l|}
\hline ACT & 0.09 & 0.14 & $\begin{array}{l}0.4 \\
1^{* * *}\end{array}$ & $0.19^{*}$ & $\begin{array}{l}0.3 \\
4^{* * *}\end{array}$ & - & & & \\
\hline OFI & 0.4 & 0.2 & 0.3 & 0.4 & 0.2 & $0.19^{*}$ & - & & \\
& $8^{* * *}$ & $3^{* *}$ & $2^{* * *}$ & $4^{* * *}$ & $4^{* *}$ & & & & \\
\hline ATI & -0.01 & $0.19^{*}$ & 0.06 & 0.07 & 0.04 & 0.08 & 0.05 & - & \\
\hline ATF & $0.22^{*}$ & 0.12 & $-0.23^{*}$ & -0.01 & 0.07 & -0.12 & -0.06 & 0.01 & - \\
\hline
\end{tabular}

Significance level: * $(\mathrm{P}<0.05), * *(\mathrm{P}<0.01)$ and $* * *(\mathrm{P}<0.001)$.

$\mathrm{IJ}=$ initial impression of juiciness, $\mathrm{SJ}=$ sustained impression of juiciness, FB = first bite impression, MFT = muscle fibre and overall tenderness, $\mathrm{AI}=$ aroma intensity, $\mathrm{OFI}=$ overall flavour intensity, $\mathrm{ACT}=$ amount of connective tissue, ATI = off-flavour indicators, ATF = a-typical flavour (ATF).

Table 4: Pearson's correlations of sensory attributes for Windsnyer pork

\begin{tabular}{|l|l|l|l|l|l|l|l|l|l|}
\hline & AI & IJ & FB & SJ & MFT & ACT & OFI & ATI & ATF \\
\hline AI & - & & & & & & & & \\
\hline IJ & $0.19^{*}$ & - & & & & & & & \\
\hline FB & $\begin{array}{l}0.3 \\
6^{* * *}\end{array}$ & $\begin{array}{l}0.5 \\
8^{* * *}\end{array}$ & - & & & & & & \\
\hline SJ & 0.2 & 0.7 & 0.6 & - & & & & & \\
& $7^{* *}$ & $8^{* * *}$ & $6^{* * *}$ & & & & & & \\
\hline MFT & $\begin{array}{l}0.2 \\
8^{* *}\end{array}$ & $\begin{array}{l}0.4 \\
8^{* * *}\end{array}$ & $\begin{array}{l}0.7 \\
5^{* * *}\end{array}$ & $\begin{array}{l}0.5 \\
9^{* * *}\end{array}$ & - & & & & \\
\hline ACT & $0.18^{*}$ & 0.3 & 0.3 & 0.2 & 0.4 & - & & & \\
& & $6^{* * *}$ & $1^{* * *}$ & $9^{* * *}$ & $3^{* * *}$ & & & & \\
\hline OFI & 0.4 & 0.3 & 0.4 & 0.4 & 0.5 & 0.3 & - & & \\
& $4^{* * *}$ & $2^{* * *}$ & $4^{* * *}$ & $2^{* * *}$ & $1^{* * *}$ & $3^{* * *}$ & & & \\
\hline ATI & 0.16 & 0.17 & 0.17 & $0.26^{* *}$ & 0.13 & 0.02 & 0.16 & - & \\
\hline ATF & $-0.28^{*}$ & -0.09 & -0.21 & $-0.25^{*}$ & -0.08 & 0.02 & -0.03 & -0.14 & - \\
\hline Signifle
\end{tabular}

Significance level: $*(\mathrm{P}<0.05),{ }^{* *}(\mathrm{P}<0.01)$ and $* * *(\mathrm{P}<0.001)$.

$\mathrm{IJ}=$ initial impression of juiciness, $\mathrm{SJ}=$ sustained impression of juiciness, $\mathrm{FB}=$ first bite impression, $\mathrm{MFT}=$ muscle fibre and overall tenderness, $\mathrm{AI}=$ aroma intensity, $\mathrm{OFI}=$ overall flavour intensity, $\mathrm{ACT}=$ amount of connective tissue, ATI = off-flavour indicators, ATF = a-typical flavour (ATF).

Table 5: Pearson's correlations of sensory attributes for boiled pork from Windsnyer and Large White gilts

\begin{tabular}{|l|l|l|l|l|l|l|l|l|l|}
\hline & AI & IJ & FB & SJ & MFT & ACT & OFI & ATI & ATF \\
\hline AI & - & & & & & & & & \\
\hline IJ & -0.06 & - & & & & & & & \\
\hline FB & 0.14 & $\begin{array}{l}0.3 \\
1^{* * *}\end{array}$ & - & & & & & & \\
\hline SJ & 0.08 & $\begin{array}{l}0.4 \\
9^{* * *}\end{array}$ & $\begin{array}{l}0.6 \\
0^{* * *}\end{array}$ & - & & & & & \\
\hline MFT & 0.09 & $\begin{array}{l}0.3 \\
9^{* * *}\end{array}$ & $\begin{array}{l}0.6 \\
5^{* * *}\end{array}$ & $\begin{array}{l}0.5 \\
7^{* * *}\end{array}$ & - & & & & \\
\hline ACT & 0.03 & $\begin{array}{l}0.3 \\
0^{* * *}\end{array}$ & $0.20^{*}$ & 0.16 & 0.3 & - & & & \\
\hline OFI & $0.21^{*}$ & $0.18^{*}$ & 0.3 & 0.4 & 0.3 & $0.22^{*}$ & - & & \\
\hline ATI & 0.01 & 0.12 & 0.07 & 0.16 & 0.10 & -0.05 & 0.10 & - & \\
\hline ATF & -0.04 & 0.03 & $-0.24^{* * *}$ & -0.08 & -0.01 & 0.07 & 0.01 & -0.14 & - \\
\hline
\end{tabular}

Significance level: *(P<0.05), ** $(\mathrm{P}<0.01)$ and $* * *(\mathrm{P}<0.001)$.

$\mathrm{IJ}=$ initial impression of juiciness, $\mathrm{SJ}=$ sustained impression of juiciness, FB = first bite impression, MFT = muscle fibre and overall tenderness, $\mathrm{AI}=$ aroma intensity, $\mathrm{OFI}=$ overall flavour intensity, $\mathrm{ACT}=$ amount of connective tissue, ATI = off-flavour indicators, ATF = a-typical flavour (ATF).

Table 6: Pearson's correlations of sensory attributes for microwave pork from Windsnyer and Large White gilts

\begin{tabular}{|c|c|c|c|c|c|c|c|c|c|}
\hline & AI & IJ & FB & SJ & MFT & ACT & OFI & ATI & ATF \\
\hline AI & - & & & & & & & & \\
\hline IJ & $0.26^{* *}$ & - & & & & & & & \\
\hline FB & 0.3 & 0.4 & - & & & & & & \\
& $1^{* * *}$ & $2^{* * *}$ & & & & & & & \\
\hline SJ & 0.3 & 0.6 & 0.6 & - & & & & & \\
& $7^{* * *}$ & $6^{* * *}$ & $4^{* * *}$ & & & & & & \\
\hline MFT & 0.2 & 0.3 & 0.7 & 0.5 & - & & & & \\
& $5^{* *}$ & $9^{* * *}$ & $5^{* * *}$ & $8^{* * *}$ & & & & & \\
\hline ACT & $0.18^{*}$ & $0.21^{*}$ & 0.4 & 0.2 & 0.4 & - & & & \\
& & & $3^{* * *}$ & $6^{* *}$ & $2^{* * *}$ & & & & \\
\hline OFI & 0.6 & $0.22^{*}$ & 0.3 & 0.3 & 0.3 & 0.2 & - & & \\
& $2^{* * *}$ & & $7^{* * *}$ & $2^{* * *}$ & $6^{* * *}$ & $7^{* *}$ & & & \\
\hline ATI & 0.10 & $0.18^{*}$ & 0.12 & 0.10 & 0.05 & 0.09 & 0.09 & - & \\
\hline ATF & -0.12 & -0.05 & -0.15 & -0.27 & -0.15 & -0.15 & -0.10 & -0.02 & - \\
\hline
\end{tabular}

Significance level: $*(\mathrm{P}<0.05), * *(\mathrm{P}<0.01)$ and $* * *(\mathrm{P}<0.001)$.

$\mathrm{IJ}=$ initial impression of juiciness, $\mathrm{SJ}=$ sustained impression of juiciness, FB = first bite impression, MFT = muscle fibre and overall tenderness, $\mathrm{AI}=$ aroma intensity, $\mathrm{OFI}=$ overall flavour intensity, $\mathrm{ACT}=$ amount of connective tissue, ATI = off-flavour indicators, ATF = a-typical flavour (ATF).

\section{Discussion}

Higher scores for initial and sustained impression of juiciness for microwaved indigenous Windsnyer pork could be due to the high level of extractable fat ${ }^{[4,27]}$. This might imply that consumers in South Africa prefer microwaved pork for indigenous pigs over Large White pigs. The current findings agree with Depres, et al. ${ }^{[7]}$ who reported preference for indigenous Creole pork over Large White. The Creole pork was distinguished from the Large White for its taste, secondary juiciness and tenderness ${ }^{[7]}$. Most meat sensory characteristics especially flavour, are influenced by the levels of intramuscular fat ${ }^{[18]}$. High level of marbling fat in pork from indigenous pigs ${ }^{[4,29]}$ was expected to enhance superior taste over the Large White, although this was not the case.

Microwaved pork had higher scores than boiled pork on aroma intensity, initial impression of juiciness, first bite, sustained impression of juiciness, amount of connective tissue, fibre and flavour intensity. These findings were unusual because microwaved pork was anticipated to lose more water ${ }^{[24]}$ and fat hence have lower juiciness and flavour scores than boiled pork. Njisane, et al. ${ }^{[22]}$ reported that microwaved beef had reduced juiciness, as well as fat content thus producing tougher meat. Pawar, et al. ${ }^{[25]}$ also reported that pork had better aroma, flavour and palatability when prepared by hot air oven than microwave although it was not tested in the current study. In a related study, Ngapo, et al. ${ }^{[20]}$ reported that pork prepared by grilling was tougher and less juicy that roasted one. It could be that the melted fat that was collected in the microwave plate, in the current study, caused the pork to become oily and affected consumers' perception. Possibly there were lower cooking losses in microwaved pork than boiled one hence increased juiciness as was also reported in beef by Toscas, et al. and Dyubele, et al. ${ }^{[18,19]}$ also observed that reactions during cooking releases many substances, such as volatile compounds, that give aroma and flavour to the meat. This may imply that many volatile compounds that 
give aroma and flavour are released through microwaving pork than boiling ${ }^{[14]}$. The results may suggest that consumers prefer microwaved over boiled pork.

The interaction between breed and cooking method had effects on fibre, amount of connective tissue, initial impression of juiciness, sustained impression of juiciness and first bite. This contradicts Dyubele, et al. ${ }^{[18]}$ who reported no interaction between the breed and the preparation method. The scores for microwaved pork from indigenous Windsnyer pork were higher than that for the microwaved Large White pork. This can be attributed to the fact that Windsnyer pork has more intramuscular fat than Large White pork ${ }^{[28]}$. Cooking method normally changes the composition of animal fat and increases the meat energy density thereby influencing sensory attributes as reported in goats ${ }^{[30]}$.

Consumer background had no effect except for a typical flavour contradicting Chulayo, et al. ${ }^{[31]}$ who reported significant tribe effects on most sensory attributes in indigenous chickens. This may be ascribed to the fact that the tribes have equal exposures and preferences to pork. Gender had effects on aroma, initial impression of juiciness; amount of connective tissue and a-typical flavour with female consumers giving higher scores than males. The findings disagree with Njisane, et al. ${ }^{[22]}$, where male consumers gave higher scores than the female consumers for most of the sensory attributes of beef. It was reported that some food items and sensory characteristics are associated with the expression of male identity, male consumers' power and domination of females ${ }^{[22]}$. It was not expected to find male consumers being more particular about the off-flavour and amount of connective tissue in pork than female consumers. This may suggest the preference of pork by female consumers than male consumers.

The Windsnyer pork had higher numerical values than Large White pork for correlations between first bite impression and initial impression of juiciness, initial impression of juiciness and sustained impression of juiciness, first bite impression and muscle fibre and overall tenderness and, between muscle fibre and overall tenderness, and sustained impression of juiciness. It could be that sensory characteristics of Windsnyer pork associate with each other better to enhance eating quality than Large White pork. Windsnyer pork was reported to have lower cooking losses and higher moisture ${ }^{[28]}$ hence it is juicier than Large White. It was reported that juiciness is a function of water content rather than cooking loss alone ${ }^{[32]}$. This in turn improves the impression on first bite and consumers will consider the pork as fairly tender ${ }^{[16,26]}$. Differences in the correlation of initial and sustained impression of juiciness between the two breeds could have been due to variation in the quantity and composition of the fat in the pork ${ }^{[33,28]}$. In general, correlations between sensory attributes were higher for microwaved pork than boiled pork. This may suggest that microwaving releases many volatile substances that enhance association of sensory characteristics to improve consumer preference ${ }^{[18,22]}$. Heddleson and Doores ${ }^{[21]}$, however, emphasised the need to use microwaves of higher wattage ( $>$ $450 \mathrm{~W}$ ) to effectively destroy pathogenic bacteria. The microbiological effect of each preparation method was, however, not assessed in the current study. In general, a-typical flavour intensity is negatively correlated to all other sensory attributes especially for different preparatory methods.

\section{Conclusion}

Windsnyer pork had higher scores on initial and sustained impression of juiciness than Large White pork. Microwave pork had higher scores for aroma, first bite impression, sustained juiciness, and amount of connective tissue, fibre and overall flavour intensity when compared to boiled pork. Gender affected sensory attributes with female consumers giving higher scores than male consumers for aroma intensity, initial impression of juiciness and a-typical flavour. Most sensory attributes were correlated to each other with higher coefficients being found in microwave Windsnyer pork than microwave Large White pork. It can be concluded that Windsnyer pork prepared by microwave is more acceptable to consumers than that for Large White pork.

\section{Conflicts of Interest}

All authors declare that there are no actual or potential conflicts of interest between the authors and other people or organizations that could inappropriately bias their work.

\section{References}

1. Visessanguan, W., Benjakul, S., Panya, A., et al. Influence of minced pork and rind ratios on physico-chemical and sensory quality of Nham a Thai fermented pork sausage. (2005) Meat Sci 69(2): 355-362.

2. Halimani, T.E., Muchadeyi, F.C., Chimonyo, M.,et al. Pig genetic resource conservation: The Southern African perspective. (2010) Ecological Economics 69(5): 944-951.

3. Bester, J. The indigenous pig in South Africa. (2010) Blackwell Publishing House.

4. Chimonyo, M., Dzama, K. and Mapiye, C. Growth performance and carcass characteristics of indigenous Mukota pigs of Zimbabwe. (2010) Tropical Animal Health and Production 42(5): 1001-1007.

5. Madzimure, J., Chimonyo, M., Dzama, K., et al. Classical Swine Fever Changes the Way Farmers Value Pigs in South Africa. (2015) JAE 66(3): 812-831.

6. Madzimure, J., Chimonyo, M., Zander, K.K.,et al. Potential for using indigenous pigs in subsistence-oriented and market-oriented smallscale farming systems of Southern Africa. (2012a) Trop Anim Health Prod 45(1): 135-142.

7. Depres, E., Naves, M., Francoise, T., et al. Growth performance and meat quality of Large White and Local pigs reared in the tropics. (1994) Livestock Research for Rural Development 2(6).

8. Chimonyo, M., Bhebhe, E., Dzama, K., et al. Improving small holder pig production for food security and livelihood of the poor in Southern Africa. (2005) African Crop Science Conference Proceedings 7: 569573.

9. Halimani, T.E., Muchadeyi, F.C., Chimonyo, M.,et al.Some Insights into population genetics of pigs in Southern Africa. (2011) A paper presented at the $44^{\text {th }}$ Congress for South African Society for Animal Science 11-14.

10. Ndiweni, P.N.B., Dzama, K. Evaluation of the indigenous pig in Zimbabwe. (1995)Harare Zimbabwe 41-44.

11. Aaslyng, M.D., Oksama, M., Olsen, E.V., et al. The impact of sensory quality of pork on consumer preference. (2007) Meat Science 76(1): 61-73.

12. Ngapo, T.M., Riendeau, L., Laberge, C.,et al. Marbling and ageing - Part 2. Consumer perception of sensory quality. (2013) Food Research International 51(2): 985-991.

13. Gatlin, L.A., See, M. T., Larick, D. K. et al. Descriptive flavor analysis of bacon and pork loin from lean-genotype gilts fed conjugated linoleic acid and supplemental fat. (2006) J Anim Sci 84(12): 3381-3386. 14. Calkins, C.R. Hodgen, J.M. A fresh look at meat flavor. (2007) Meat 
Science 77(1): 63-80.

15. Muchenje, V., Hugo, A., Dzama, K., et al. Cholesterol levels and fatty acid profiles of beef from three cattle breeds raised on natural pasture. (2009) Journal of Food Composition and Analysis 22(4): 354-358. 16. Aaslyng, M.D., Bejerholm, C., Ertbjerg, P., et al. Cooking loss and juiciness of pork in relation to raw meat quality and cooking procedure. (2003) Food Quality and Preference 14(4): 277-288.

17. Muchenje, V., Dzama, K., Chimonyo, M., et al. Sensory evaluation and its relationship to physical meat quality attributes of beef from Nguni and Bonsmara steers raised on natural pasture. (2008) Animal 2(11): 1700-1706.

18. Dyubele, N.L., Muchenje, V., Nkukwana, T.T., et al. Consumer sensory characteristics of broiler and indigenous chicken meat: A South African example. (2010) Food Quality and Preference 21: 815- 819.

19. Toscas, P. J., Shaw, F. D., Beilken, S. L. Partial least squares (PLS) regression for the analysis of instrument measurements and sensory meat quality data. (1999) Meat Science 52: 173-178.

20. Ngapo, T.M., Riendeau, L., Laberge, C., et al. Marbling and ageing - Part 1. Sensory quality of pork. (2012b) Food Research International 49(1): 396-405.

21. Heddleson, R.A., Doores, S. Factors affecting microwave heating of foods and microwave induced destruction of foodborne pathogens - a review. (1994) Journal of Food Protection 57(11): 1025-1037.

22. Njisane, Y.Z., Muchenje, V., Gajana, C.S. Effects of consumer background on sensory scores of microwaved Angus loins. (2012) African Journal of Biotechnology 11(6): 1443-1448.

23. Omojola, A.B., Fagbuaro S.S., Ayemi, A.A. Cholesterol content, physical and sensory properties of pork from pigs fed varying levels of dietary garlic. (2009) World Applied Sciences Journal 6(7): 971-975.

24. Hoda, I.S. Ahmad, S., Srivastava, P.K. Effect of microwave oven processing, hot air oven cooking, curing and polyphosphate treatment on physico-chemical, sensory and textural characteristics of buffalo meat products. (2002) Journal of Food Science Technology 39(3): 240245.
25. Pawar, V.D., Khan, F.A., Agarkar, B.S. Effect of fat/whey protein concentrate levels and cooking methods on textural characteristics of chevon patties. (2002) Journal of Food Science and Technology 39(4): 429-431.

26. Mohammad N.P.U., Chatli, M.K., Sharma, D. K.,et al. Effect of cooking methods and fat levels on the physico-chemical, processing, sensory and microbial quality of buffalo meat patties. (2010) Asian-Australian Journal of Animal Science 23(10): 1380-1385.

27. Madzimure, J., Chimonyo, M., Zander, K.K.,et al. Diurnal heat-related physiological and behavioural responses in South African indigenous gilts. (2012b) Journal of Arid Environments 87: 29-34.

28. SAS/STAT User's Guide, Release 9.1.3. (2006)Statistical Analysis Systems (SAS).

29. Madzimure, J. Climate change adaptation and economic valuation of local pig genetic resources in communal production systems of South Africa. (2011).

30. Xazela, N.M., Chimonyo, M., Muchenje, V.,et al. Consumer Sensory Evaluation of Meat from South African Goat Genotypes Fed on a Dietary Supplement. (2011) African Journal of Biotechnology 10(21): 4436-4443.

31. Chulayo, A.Y., Muchenje, V., Mwale, M.,et al. Effects of some medicinal plants on consumer sensory characteristics of village chicken meat. (2011) African Journal of Biotechnology 10(5): 815-820.

32. Bertram, H. C., Purslow, P. P., Andersen, H. J. Relationship between meat structure, water mobility and distribution: a low field NMR study. (2007) Journal of Agricultural and Food Chemistry 50(4): 824-829.

33. Wood, J.D.,Enser, M. Factors influencing fatty acids in meat and the role of antioxidants in improving meat quality. (1997) British Journal of Nutrition 78(1): S49-S60.
Online ISSN: 2377-0619

Journal Title: International Journal Food and Nutritional Science Journal Short Name: Int J Food Nutr Sci
Ommega Online Publishers

E-mail: editor.foodscience@ommegaonline.com Website: www.ommegaonline.org 